ROCZNIKI FILOZOFICZNE

Tom LXVIII, numer $4-2020$

DOI: https://doi.org/10.18290/rf20684-8

ANDRZEJ MARYNIARCZYK

\title{
METAPHYSICAL CREATIONISM AND THE PARADOXES \\ OF EVOLUTIONARY THEISM: A CONTRIBUTION TO THE DISCUSSION WITHIN CONTEMPORARY THOMISM
}

\section{INTRODUCTION}

The metaphysical creationism that we encounter in the philosophy of Saint Thomas Aquinas, as opposed to American creationism ${ }^{1}$ and theological-biblical creationism, is a theory that stems from a purely philosophical explanation of the origins of the world and man. It is not, therefore, a biblical idea transferred to philosophy. Just like the theism of Aristotle's metaphysics, the theism of metaphysics of Aquinas is not a religious (theological) theism, but a purely philosophical (metaphysical) one, as it stems from a metaphysical explanation of reality. Metaphysical creationism is the ultimate explanation of the source of the existence of beings that are given to our experience as both unnecessary in their own existence and changeable.

On the other hand, American creationism, with which Polish and foreign naturalists and philosophers of nature argue, is either a biological-cosmo-

The project is funded by the Minister of Science and Higher Education under the program "Regional Initiative of Excellence" 2019-2022; project no. 028/RID/2018/19; the amount of funding: $11,742,500$ PLN.

Prof. Dr. Habil. AndRzej MaryniarczyK SDB, The John Paul II Catholic University of Lublin, Faculty of Philosophy, Department of Metaphysics.

${ }^{1}$ American creationism is a religious theory, and therefore the plane of discussion should be religious (that is, it should be an interpretation of the biblical text). Hence, Bible scholars (Protestant, Jewish, and Catholic) should argue among themselves about the correct interpretation of the biblical narrative concerning the creation of the world, not philosophers, biologists, or naturalists. So, this is a mix-up of competencies. Natural philosophers and others, in going into battles with American creationists (or into discussion with religious theories of creationism), should be reminded of those with whom they would like to argue, as the subject of American creationism is the theological concept of God, even though the philosopher's point of view remains philosophical. 
logical interpretation of the biblical truth of the world's creation (within a certain 7-day time frame and in referring to the data of Revelation, which American creationism thus wants to confirm scientifically) or a theory built within the contemporary natural and cosmological sciences and dominated in the explanation it gives by a methodological apparatus taken from the theory of evolution. ${ }^{2}$ For this reason, in this article we will not refer to individual authors who deal with the problems of creationism in the Polish philosophy of nature, or to their arguments, because the plane of their discussion is not metaphysical creationism. Therefore, it is not a matter of ignoring the efforts of the authors who take up the problem of evolutionary theism in their discussions and their arguments, but of avoiding confusion which would give the impression that the author of this article is entering the space and plane of these discussions. The choice of such an approach was dictated by the fact that: first of all, most Polish and foreign authors do not pay attention to the fact that the proper level of discussion of the problem of the beginning of the world and of man is not the natural sciences or natural philosophy itself, but rather metaphysics. Second, the authors of most studies do not distinguish between American creationism, natural creationism, and metaphysical creationism, and for this reason the totality of argumentation does not meet itself and thus goes two separate ways. Third, the author of this work concentrates on the paradoxes of Thomistic evolutionary theism, which is built on the basis of metaphysics. Fourth, metaphysical creationism is a purely philosophical theory, unlike biblical, natural, or cosmological theories, and is a consequence of metaphysical interpretation of the whole of reality.

This article is divided into two parts. The first one presents the key elements of metaphysical creationism, i.e., the metaphysical (not theological, biblical, or natural) theory of creation ex nihilo and how one should under-

\footnotetext{
${ }^{2}$ Most of the works of Polish natural philosophers (Ludwik Wciórka, Kazimierz Kloskowski, Kazimierz Jodkowski, Józef Życiński, Michał Heller, Tadeusz Pabjan, Piotr Bylica, and others) are concerned with discussions with American creationism, which is in essence a mixture of Protestant biblical theology and natural sciences, and thus do not concern themselves with metaphysical creationism, which is not known to the representatives of American creationism or their opponents. For this reason, we will not refer to these works and to these discussions. See, for example: Kazimierz Jodkowski, Spór ewolucjonizmu z kreacjonizmem. Podstawowe pojęcia i poglady (Warsaw: Megas, 2007); Kazimierz KLosKowski, Filozofia ewolucji i filozofia stwarzania (Warsaw: Wydawnictwo ATK, 1999); Józef ŻYciŃsKI, Bóg i stworzenie. Zarys teorii ewolucji (Lublin: Gaudium, 2011); Życiński, God and Evolution. Fundamental Questions of Christian Evolutionism, trans. Kenneth W. Kemp and Zuzanna Maślanka (Washington, DC: Catholic University of America Press, 2006). In these works the authors do not go beyond the biblical concept of creationism characteristic of American and Protestant creationist groups.
} 
stand this theory. The second part presents the elements of evolutionary theism-elements which are currently propagated within the framework of Thomistic philosophy and which (from the perspective of metaphysical creationism) are the sources of various paradoxes and, at times, even absurdities, and thus demand reconsideration. For this reason, the second part of the article is not a polemic concerning some specific authors, but a direct polemic discussing theses formulated by some Thomistic representatives of evolutionary theism, and as such only indirectly concerns the supporters of evolutionary theism (or, as they like to call it, "theistic evolutionism") as formulated on the basis of other trends in philosophy and natural sciences. ${ }^{3}$

\section{WHAT IS METAPHYSICAL CREATIONISM AND WHAT CONSTITUTES IT?}

Three elements constitute the philosophicality of metaphysical creationism: its starting point, method, and the purpose of explanation. ${ }^{4}$ The starting point (1) is a reference to the experience of being, which is the direct object of cognition and explanation. The starting point of Aquinas's metaphysics is the experience of being, which is first given as "something that exists" (the existing John), as something composed of essence and existence (the existential concept of being), and, secondarily, as something properly formed and changeable. This indication of the primary character of existence in relation to changeability (because something must first exist for it to change), coupled with the distinction between changeability and accidental character, became the basis for the formulation of the metaphysical theory of creatio ex nihilo. Hence, as a consequence of metaphysical explanations, the Absolute appears as the Author/Source of being and the existence thereof - the One that does not arise from anything that was already present before: the Creator.

\footnotetext{
${ }^{3}$ In this article I consciously use the term "evolutionary theism" instead of "theistic evolutionism," for the reason that the issues of this work are limited to discussions within Thomism (and not within evolutionism in general). In traditional Thomism, we encounter "metaphysical theism"- and only such. Meanwhile, there appears a group of philosophers who declare themselves to be Thomists and at the same time want to transform "metaphysical theism" into "evolutionary theism," and also to include this in the philosophy of Aquinas. These activities, I believe, are irreconcilable.

${ }^{4}$ Mieczysław A. KrąPIEC and Stanisław KAmiŃski, "The Specificity of Metaphysical Cognition. Specyficzność poznania metafizycznego," in Stanisław KAMIŃski, On the Metaphysical Cognition. O poznaniu metafizycznym (Lublin-Rome: PTTA 2020), $19 \mathrm{ff}$.
} 
The second element (2) proving the philosophicality of metaphysical creationism is the methods of explanation and justification. ${ }^{5}$ The main feature of this method of explanation is looking for, and pointing to, causes. ${ }^{6}$ However, the problem of creative causation, which appears in the metaphysics of St. Thomas Aquinas, exceeds the explanation in question by referring to the theory of four causes inherited from Aristotle. Creative causation concerns the creation of being in the absolute sense, i.e., it is the introduction of the whole of being into existence together with its form and matter, substance and accidents, and essence and existence. Even more, beings do not arise from something that was already there before. Creative causation concerns the creation of being in the absolute sense; that is to say, creative causation is the introduction of the whole being into existence together with its form and matter, substance and accident, essence and existence. Even more, beings do not arise from something that was already there before. For this reason, Aquinas reaches for Plato's theory of participation, greatly criticized by Aristotle, and reinterprets it not in terms of the theory of reflection or participation, but in terms of the theory of creative causation, and, on top of that, in terms of creative causation ex nihilo. The Absolute/Creator, therefore, is the cause of the creation of the whole being. He accomplishes this through an act of the intellect and will, and for this reason He is the efficient cause of that being - of its form, its design, and purpose. The Absolute/ Creator endows a being with everything that makes a being a being. Aristotle's Absolute gave the world and beings only movement, thanks to which the forms of beings emerged from the potency of matter and was the ultimate reason of this process. In Aquinas's thought, the Creator introduces the whole being into existence.

The third element (3) is the purpose of metaphysical explanation, and in this case the purpose is to indicate the ultimate cause of the world's existence. It is worthwhile noting that for the Pre-Socratic philosophers, as well as for Plato and Aristotle-who held the view that the world as a whole existed eternally - the aim of searching for the cause of existence did not con-

\footnotetext{
5 "There are two general features characteristic to the course of thinking aimed at proving something that are (and should be) always complied with, to a greater or lesser degree, in the field of the philosophy of being: (1) interpretation of the states of things from the perspective of the previously and justifiably constructed concept of being as being (being as the existing one) and (2) historicism" (KRĄPIEC and KamińsKi, Specyficzność, 44-45).

${ }^{6}$ More on this can be found in Stanisław KAMIŃSKi, "Explanation in Metaphysics. Wyjaśnianie w metafizyce," in Stanisław KAmí́ski, On the Methodology of Metaphysics. Z metodologii metafizyki (Lublin-Rome: PTTA, 2018), 176-202.
} 
cern the whole world, but only its fragments (material beings). No wonder, then, that these philosopher's theories of the creation of the world, first of all, did not explain the creation of the world in an absolute sense, that is, in its entirety, but only the creation of the material world. Secondly, these philosophers accepted, in a peculiarly a priori manner, the eternal existence of some kind of substrate for the creation of the beings of this world: preelements (the pre-Socratic philosophers), ideas, numbers and laws (Plato), first matter and first heavens (Aristotle). Thirdly, the search for an answer to the question concerning the ultimate cause of the creation of beings had to be limited to beings of the material world. Even more, the absolutization of physical-natural explanations, together with an attempt to give them the status of metaphysical explanations (the aim of which is to search for the causes of the existence of the whole world), meant an overstepping of the boundaries of methodological competence. For this reason, the proposed explanations could not be treated as strictly metaphysical, as covering the whole of all things, but as natural (physical) explanations concerning only a fragment of the material world.

The inaccuracy and inconsistency were noticed by Aquinas. No wonder, then, that he emphasized the need to formulate such a theory of philosophical explanation of the creation of the world that would subsequently cover the whole world; that is, a theory in which the question of the universal cause of all things arises. The search for an answer to the question about the universal cause, that is, the reason for the existence of everything (pre-elements, the world of ideas, numbers and laws, matter and first heavens, etc.) belongs to the competence of metaphysical explanation.

\section{THE TRANSFER OF EXPLANATION FROM PHILOSOPHY OF NATURE TO METAPHYSICS}

Thomas Aquinas, when formulating the philosophical theory of creatio ex nihilo, draws attention to two important issues related to the explanation of the formation of beings: firstly, to the very understanding of the fact of the formation of things and secondly, to what type of explanation this issue has thus been ascribed so far, and to what kind of explanation it actually belongs. For this reason, Aquinas makes some important observations. And so, he notes that in the deliberations of ancient naturalists (the so-called philosophesantes), as well as in the deliberations of Plato and Aristotle, the prob- 
lem of the formation of beings was narrowed (reduced) to the material world only. The Ionian philosophers, Plato, as well as Aristotle himself all linked the emergence of beings only to the material world (Aristotle talked about the sub-lunar world). This emergence, this formation did not concern pre-elements, the world of ideas, and the first matter and the first heavens - these having existed for centuries previously-but the formation thereof concerned only a fragment of the world, namely the physical (material) world. For this reason, the search for the causes of the emergence of beings was carried out by naturalists and the philosophy of nature was considered to be the proper field, the competence of which included this type of research (this was the 'natural science' of the day). ${ }^{7}$ Furthermore, Aquinas points out that the ancient philosophers treated the very creation of things as an activity that is accidental and not absolute. This means that they treated this formation as the regrouping of elements, a thinning or thickening, a forming and reshaping of matter, a passing from potency to act, and not the complete creation of substance as such. No wonder that some of these philosophers reduced the formation of things to purely external activities, while others opted for internal activities. The former, as Aquinas explains, "sought the beginning of individual things [and] considered only the formation of concrete beings, examining how this fire or this stone arises. And therefore, the former, considering the creation of things from the outside more than they should have done, claimed that things are only created according to certain accidental states, such as thinness, density and the like. They could therefore say that creation is nothing but change, because they understood that everything was created from an actual being." ${ }^{\circ}$ The latter philosophers, on the other hand, reduced the formation of things to certain internal processes such as the actualization of potency, and maintained that "things do not have to come from an actual being, perhaps accidentally, but they come by themselves from being in potency. Such a coming into existence, namely, of any being, from any being, is the coming into existence of a specific being which comes into being as that being, such as man or fire, and not as being as being. Thus, they claimed that there was an earlier being which is transformed into this being." ${ }^{.9}$ This type of

\footnotetext{
${ }^{7}$ This is worth emphasizing, because even today all kinds of discussions on the creation of the world, as well as of creationism or evolutionism, have been reserved for the philosophy of nature, cosmology, or physics.

${ }^{8}$ Thomas Aquinas, Summa contra Gentiles, lib. 2 cap. 37 (vol. 2, ed. Pietro Caramello, Pietro Marc, and Ceslas Pera [Taurini: Marietti, 1961].

${ }^{9}$ Ibid. This text is based on the Polish translation: Summa contra Gentiles. Prawda wiary chrześcijańskiej, vol. 1, trans. Zofia Włodek and Włodzimierz Zega (Poznań: W Drodze, 2003).
} 
creation is characteristic only for material beings, and the explanation for such a forming is provided by the natural sciences.

The purpose of this explaining, within the framework of the natural sciences and the philosophy of nature, is to search for the reasons which are necessary but closest to the things that arise. And so, for a specific John, his closest and necessary cause is his mother and father, and for them John's grandmothers and grandfathers, etc. The same is true of animals, plants, and inanimate objects that come into being. Whenever something (someone) comes into being, it comes from something (someone). However, during this type of explanation, which is characteristic of the natural sciences (the philosophy of nature), nobody asks about the reason why everything is created, that is, about the universal cause. Hence the need for some eternal substrate: the pre-elements (Ionians), the sphere of ideas, laws and numbers (Plato), the first matter and the first heavens (Aristotle). In turn, the search for the cause of the existence of everything that exists, i.e., the universal cause, lies within the competence of metaphysics, not the philosophy of nature.

For this reason, Aquinas formulates an important conclusion that the study of "this kind of beginning of things does not belong to the philosopher of nature, but to the metaphysician, who studies being as being and that, within which there is no movement" (emphasis mine). ${ }^{10}$ Therefore, it is necessary to transfer the inquiries concerning the creation of the world in general, as well as of individual beings, from the philosophy of nature and the natural sciences to the area of metaphysics. It is up to metaphysics to investigate the ultimate causes of the existence of the world and everything that constitutes it.

\section{THE PRINCIPLE EX NIHILO NIHIL FIT AND THE THEORY OF CREATIO EX NIHILO}

The philosophical theory of creatio ex nihilo formulated by Thomas Aquinas appeared contrary to the common opinion, according to which things, if they arise, always arise from something, and the whole world arises from a pre-existing, prehistoric raw material (matter) or from eternal

\footnotetext{
10 "Propter quod nec ad naturalem philosophum pertinent huiusmodi rerum originem considerare: sed ad philosophum primum, qui considerat ens commune et ea qua esunt separata a motu. Nos tamen sub quadam similitudine etiam ad illam originem nomen factionis transferimus, ut dicamus ea facta quorum cumque essentia vel natura ab aliis originem habet" $(C G$, lib. 2 cap. 37).
} 
ideas, and nothing arises from nothing (ex nihilo nihil fit). The theory of creatio ex nihilo, which Aquinas introduces into the bloodstream of philosophical (metaphysical) explanation, is formulated in the context of the then commonly held notion of the eternal existence of some raw material, from which something is created and, in a way, in opposition to this belief. Hence the formulation of the creatio ex nihilo theory contains a negative message, namely, this theory states that "the world did not arise from something that was already there" (from some pre-elements, ideas, or first matter), and thus everything in the world comes from a first cause: matter and form, substance and accidents, and the essence and existence of being.

Before beginning to formulate the theory of creatio ex nihilo, St. Thomas Aquinas begins by reinterpreting a commonly held belief in philosophy (opinio communis), according to which things always come from something that was always there, and after the break-up or decay of a thing this something is precisely what remains. Whatever comes into being always comes out of something, and nothing comes out of nothing (ex nihilo nihil fit). This was a very difficult and at the same time very delicate problem for him. Aquinas himself often referred to the opinio communis (common belief) in various discussions and used this reference as an argument against skepticism and agnosticism, among other things. On the other hand, however, Aquinas was aware that he must dare to, if not to reject, then at least suspend the opinio communis that indicates the need for the existence of an eternal substrate, from which beings arise - in order to identify the problem of the creation of beings and of the world in an absolute (and not accidental) sense, with this being the content of the creatio ex nihilo theory. ${ }^{11}$

For this reason, Aquinas first reminded us of the nature of the human intellect, which is oriented towards knowing the truth, so that all people not only strive to know the truth, but also achieve it. This fact is confirmed by the formulated common beliefs (opinio communis) that people come to regarding important matters in different times and cultures. Therefore "what everyone says cannot be completely false." $"$ If this were not the case, it

\footnotetext{
11 "Ex hoc autem confutatur error antiquorum philosophorum qui ponebant materiae omni nonullam causam esse, eo quod actionibus particularium agentium semper videbant aliquid actio praeiacere: ex quo opinionem sumpserunt, omnibus communem, quod ex nihilo nihil fit. Quod quidem in particularibus agentibus verum est. Ad universalis autem agentis, quod est totius esse activum, cognitionem nondum pervenerant, quem nihil in sua actione praesupponere necesse est" (CG, lib. 2 cap. 16).

12 "Quod enim ab omnibus communiter dicitur, impossibile est totaliter esse falsum. Falsa enim opinio infirmitas quaedam intellectus est: sicut et falsum iudicium de sensibili proprio ex
} 
would be the evidence of some permanent disability of our intellect. This in turn would open the door to all kinds of skepticism and agnosticism because if so many people are wrong about some truth, they can be wrong about any truth. Thus, truth becomes unattainable or relative. Meanwhile, Aquinas draws attention to the fact that all defects are something accidental and cannot be always and in everything. Therefore, the judgment passed by everyone cannot be false. "It is the common conviction of all philosophers that there can be no being out of non-being," as Aristotle wrote in the first book of Physics, and as Aquinas recalled. ${ }^{13}$

Therefore, Aquinas did not intend to undermine the role of the opinio communis in scientific (truth-oriented) cognition and thus arbitrarily reject it. He considered the opinion of his predecessors concerning the eternity of the world as a whole and the eternal existence of primordial material, from which the world came into being, to be true and valid - but only under four conditions, namely that (1) one would accept the mental context of the ancient philosophers in which this universal conviction came into being, (2) one would explain one's own understanding of the coming into being of things, (3) one would define the method used by philosophers to explain the coming into being of things, and (4) one would pay attention to the field of philosophy (science), in which this opinion came into being and was deemed valid (the philosophy of nature).

Taking all this into account, Thomas Aquinas formulated his first binding conclusion: it was within the explanations given by the philosophy of nature (naturalists) that the common opinion arose, which stated that ex nihilo nihil fit - and this opinion is therefore binding for that circle only. This type of explanation of the creation of beings and the chosen method of explanation were the basis for the formation of a common conviction (opinio communis) that something always comes from something else, and ex nihilo nihil fit (nothing comes from nothing). However, this is not a final explanation concerning the whole of all things and does not give an adequate answer to the question: Diati?-Why? - Why do the whole world and being exist at all?

\footnotetext{
infirmitate sensus accidit. Defectus autem per accidens sunt: quia praeter naturae intentionem. Quod autem est per accidens, non potest esse semper et in omnibus: sicut iudicium quod de saporibus ab omni gustu datur, non potest esse falsum. Ita iudicium quod ab omnibus de veritate datur, non potest esse erroneum" ( $C G$, lib. 2 cap. 34).

13 "Communis autem sentential est omnium philosophorum ex nihilo nihil fieri" ( $C G$, lib. 2 cap. 34).
} 
There then appears also the second binding conclusion, which Aquinas formulates, namely that so far this kind of problem has not been the subject of metaphysical reflection, and therefore, in the area of metaphysical explanation, this type of opinio communis (that of ex nihilo nihil fit) was never formulated. ${ }^{14}$ No wonder that not only ancient naturalists, but also Aristotle himself in his cosmogony, remained philosophers of nature and were not metaphysicians.

So, we see how precisely and at the same time rationally Aquinas solves the problem of the opinio communis that ex nihilo nihil fit and at the same time opens the way for the formulation of a metaphysical theory of creatio ex nihilo. Moreover - and this should be emphasized-he points out that the field of philosophy, in which competence lies in investigating the ultimate causes of the existence of all things and of the whole world, is metaphysics, not philosophy of nature (or natural sciences). ${ }^{15}$

However, the suspension of the validity of the opinio communis with regards to the principle that ex nihilo nihil fit does not mean that Aquinas bases his creatio ex nihilo theory on the principle "ex nihilo ens fit" (from nothing being is created). The essence and the main message of the revolutionary theory of creatio ex nihilo is to prove that everything that is comes from the First Cause, which is not non-being, but is the first and only Source of the existence of the whole world and everything that is in it: matter and form, substance and accident, essence and existence, and simply the whole of being.

\section{WHAT IS EX NIHILO CREATION?}

St. Thomas Aquinas noted that the generatio (birth, formation) proclaimed by the ancient philosophers as the principle of the creation of things should be treated as a mutatio (change), which in his opinion cannot be identified with creatio. Generatio, defined as the transition from potency to act, presupposes a priori the eternal existence of the matter and forms potentially contained in it. Yet creatio is not the transformation of some matter, but the complete

\footnotetext{
14 "Ad universalis autem agentis, quod est totius esse activum, cognitionem nondum pervenerant, quem nihil in sua actione praesupponere necesse est" $(C G$, lib. 2 cap. 16).

${ }^{15}$ It is worth noting that the majority of publications, discussions, and analyses concerning cosmogony take place in the area of the philosophy of nature, physics, cosmology, or the natural sciences. These issues are still absent in the area of metaphysics, including existential metaphysics. Hence, one of the main tasks of contemporary existential metaphysics should be to remind and popularize the metaphysical theory of creatio ex nihilo and to introduce it permanently into the didactics of metaphysics.
} 
calling of some matter into existence, along with the created being. ${ }^{16}$ Furthermore, it must be remembered that both change (mutatio) and birth (generatio), which Aristotle treated as a manifestation of contingent (unnecessary) existence, must be linked to some pre-existing, eternal substrate as its subject. Thus, the act of creation cannot be defined in terms of change or movement, since this necessarily involves the adoption of an eternal substrate. ${ }^{17}$

The metaphysical theory of creatio ex nihilo, although it was formulated by Aquinas to rationalize the biblical interpretation of the creation of the world and man, has not been transferred from the Bible, or theology, to philosophy. Just as Aristotle's theory of the Absolute (God) as the First Immovable Mover is a consequence of philosophical (metaphysical) explanation of the source of movement in the world, so too is the philosophical (metaphysical) theory of creatio ex nihilo a consequence of explaining and justifying the source of the existence of the world, which is a set of contingent (not necessary) beings, that is, beings that do not have, in their ontological structure, the reason of their existence. ${ }^{18}$

The main impulse to formulate the philosophical theory of creation ex nihilo was Aquinas's discovery of the new, fundamental compositions of being: essence and existence and their non-identity, thanks to which things really and truly exist and subsequently undergo various changes and transformations, such as: formation, birth, change and improvement, death, etc. These compositions - instead of the Aristotelian compositions of matter and form (hylemorphism) - promote a new, existential concept of being and introduce into the area of philosophical explanation the issue of existence and the question of its source, and therefore the question of the efficient creative cause, with this being previously unknown to philosophers. ${ }^{19}$

Aquinas was one of the first philosophers to question (as rationally unjustified and a priori accepted) the view of the eternal existence of both the

\footnotetext{
16 "Deus res in esse produxit ex nullo praeexistente sicut ex materia. Si enim est aliquid effectus Dei, aut praeexistit aliquid illi, aut non. Si non, habetur propositum: scilicet quod Deus aliquem effectum producat ex nullo praeexistente. Si autem aliquid illi praeexistit, aut est procedere in infinitum, quod non est possibile in causis naturalibus, ut philosophus probat in II metaphysicae: aut erit devenire ad aliquod primum quod aliud non praesupponit. Quod quidem non potest esse nisi ipse Deus" ( $C G$, lib. 2 cap. 16).

${ }^{17}$ Cf. $C G$, lib. 2 cap. 19.

${ }^{18}$ More on this can be found in: Andrzej Maryniarczyk, Dlaczego stworzenie 'ex nihilo', Teoria metafizycznego kreacjonizmu (Lublin: PTTA, 2018); Grzegorz SzUMERA, Metafizyka stworzenia. Świętego Tomasza z Akwinu teoria creatio ex nihilo (Lublin: Towarzystwo Naukowe KUL, 2017).

${ }^{19}$ Andrzej Maryniarczyk, “'Parvus Error in Principio Magnus Est in Fine.' Thomas Aquinas's Reinterpretation of the Understanding of Being and Essence as the Basis for the Discovery of the First Cause as 'Ipsum Esse'," Roczniki Filozoficzne 67, no. 4 (2019): 27-51.
} 
world as a whole and of matter (and possibly ideas) which was shared by ancient philosophers also including Plato and Aristotle. According to Aquinas, neither matter itself nor form, nor the composition of matter and form is sufficient to explain the existence of a concrete thing and the whole world. ${ }^{20}$

For this reason, both the creation of things and their current existence cannot be explained by reference to the principle of passing from potency to act. Movement, change, creation, as well as birth-understood as a transition from potency to act-always presuppose the earlier existence of a substrate and for this reason they cannot be identified with the act of introducing the whole of being into existence, that is, creation. Therefore, the cause of movement and transformation cannot be identified with the cause, which calls beings into existence, in the sense of the totality of their existence (in the absolute sense). All this led Thomas Aquinas to the discovery of a new efficient cause of existence, unknown until then in philosophy, namely, the Creative cause, which is the ultimate and only cause that explains the existence of the world in general, as well as of individual beings that do not have the reason of their own existence because they are unnecessary and therefore also accidental. ${ }^{21}$

\subsection{Specificity of the Act of Creation Ex Nihilo}

Creation, as Aquinas explains, "is not a form of movement or any kind of change, understood as an actualization of potency as such, nor a composing or emanating. ${ }^{22}$ Every movement or change is an actualization of something

\footnotetext{
20 "Necessitas autem ordinis ad id quod non est per se necesse esse, non cogit aliquid semper fuisse: sequitur enim, si aliquid currit, quod moveatur; non tamen necesse est quod semper motum fuerit, quia ipsum currere non est per se necessarium. Nihil ergo cogit creaturas semper fuisse" $C G$, lib. 2 cap. 31 . The topic is continued in cap. 32-38.

${ }^{21}$ In analyzing Aquinas's path leading to the formulation of the metaphysical theory of creatio ex nihilo, one can point to two sources of inspiration. One of them is the biblical description and teaching of the Fathers of the Church, and the other is the perception of the overtly contradictory and absurd elements of explanations given in philosophical cosmogonies. The biblical teaching concerning the creation of the world contained in Genesis $(1: 1-2,4 a)$, the books of Maccabee (2 Mac 7:28), and other biblical texts were well known to Thomas Aquinas, as well as the views of the Church Fathers, Jewish philosophers (Moses ben Maimon), and even Arabic philosophers (Avicenna, Averroes), and were undoubtedly an inspiration and a stimulus to question Aristotle and his predecessors about the validity and legitimacy of their beliefs regarding the eternal existence of the world and the existence of some substrate (material or immaterial, i.e., ideas).

22 "Dei actio, quae est absque materia praeiacente et creatio vocatur, non sit motus neque mutatio, proprie loquendo" ( $C G$, lib. 2 c. 17).
} 
that exists in potency. ${ }^{23}$ The extreme objects of change and movement (extrema motus vel mutationis) always belong to the same order as movement and change or share one and the same potency (e.g., a lack and form in birth and decay). Creation is therefore not an actualization of potency, nor is it an action aimed at something [already existing]. ${ }^{24}$ In every movement or change there must be something "before" and "now." However, creation is a calling to existence of the whole substance of a thing. ${ }^{25}$ Acts of creation can be understood as "actions" or "changes" only because of our way of cognizing (secundum modum intelligendi tantum) and not because of the way they are carried out. Aquinas understands the effect of creation as something that first did not exist and then appeared, that is, as something that happened after "not being there." Hence our reason "accepts one and the same thing as first non-existent and then existing." 26 He points out that creation can only be metaphorically called change or movement-in the sense that the created thing has an existence after non-existence. It is also figuratively said that one thing comes into being from another where one thing does not change into another, but only follows another (e.g., day after night) ${ }^{27}$

In his argumentation in favor of creatio ex nihilo, Aquinas pays particular attention to the proper understanding of efficient creative cause, which is the cause of the existence of all beings. This must be the first in relation to those beings which arise as a result of its action. ${ }^{28}$ Creation means that a being did not originate from something but received its existence after its non-existence. ${ }^{29} \mathrm{In}$

\footnotetext{
${ }^{23}$ Cf. ibid.

${ }^{24}$ Cf. ibid.

${ }^{25} \mathrm{Cf}$. ibid.

${ }^{26} C G$, lib. 2 cap. 18.

${ }^{27}$ Cf.: "Creatio mutatio dici non potest nisi secundum metaphoram, pro ut creatum consideratur habere esse post non esse: ratione cuius aliquid ex alio fieri dicitur etiam eorum quae invicem transmutationem non habent, ex hoc solo quod unum eorum est post alterum, sicut dies ex nocte. Nec ratio motus inducta ad hoc aliquid facere potest: nam quod nullo modo est, non se habet aliquo modo; ut possit concludi quod, quando incipit esse, alio modo se habeat nunc et prius" (CG, lib. 2 cap. 37).

28 "Esse autem dicitur de omni eo quod est. Impossibile est igitur esse aliqua duo quorum neutrum habeat causam essendi, sed oportet utrumque acceptorum esse per causam, vel alterum alteri esse causam essendi. Oportet igitur quod ab illo cui nihil est causa essendi, sit omne illud quod quocumque modo est. Deum autem supra ostendimus huiusmodi ens esse cui nihil sit causa essendi. Ab eo igitur est omne quod quocumque modo est. Si autem dicatur quod ens non est praedicatum univocum, nihil minus praedicta conclusio sequitur. Non enim de multis aequivoce dicitur, sed per analogiam: et sic oportet fieri reductionem in unum" ( $C G$, lib. 2 cap. 15).

29 "Igitur proprius modus suae actionis est ut producat rem subsistentem totam, non solum rem inhaerentem, scilicet formam in materia. Per hunc autem modum agit omne agens quod
} 
calling things into existence in their entirety, Aquinas sees an expression of the supreme power and goodness of the Creator. Hence, for Aquinas, the answer to the question of why the world came into being is that it did not come into being out of any necessity and also did not come into being from something that was already there. Beings that have been brought into existence by an act of intellect and will are a witness and a sign of the love and the free and rational will of the Creator. Therefore, also in this action, the principle of metaphysical explanation is preserved, which states that ex nihilo nihil fit, because those beings were not derived from nothingness or non-being, but from the intellect and the will of the Creator.

\subsubsection{Creation as Productio Rei ex Nihilo}

Characterizing the philosophical theory of creation ex nihilo, attention should be paid to two key phrases used by Aquinas. The first is the definition of creation as "the introduction of being into existence" (productio rei ad esse ex nihilo), ${ }^{30}$ and the second is that creation is the introduction and constitution of first relations as well as the dependency of created beings on that which is their beginning (the Creator)—ipsa dependentia esse creati ad principium a quo statuitur. ${ }^{31}$

At first glance, the verb producere is a weaker expression indicating the formation of beings as compared to the verb creare. However, this seemingly small "substitution" of the word is essential. The term creatio, together with its Greek equivalents: ktisis or genesis, and also poiesis, indicate above all the power of the Creator, not the act of creation itself. This power can be expressed in organizing chaos, bringing something from potency to act, designing, etc. Hence, many philosophers have reconciled the theory of creation with a simultaneous belief in the eternal existence of the world. They understood creation as an act of producing, and thus an activity of organizing or shaping.

materiam in agendo non requirit. Deus igitur materiam praeiacentem non requirit in sua action" (CG, lib. 2 cap. 16).

30 "Patet etiam ex praedictis quod multitudo actionum quae Deo attribuitur, ut intelligere, velle, producere res, et similia, non sunt diversae res" ( $C G$, lib. 2 cap. 10); "Deus igitur ... potest producere res in esse" (CG, lib. 2 cap. 16).

31 "Non enim est creatio mutatio, sed ipsa dependentia esse creati ad principium a quo statuitur. Et sic est de genere relationis. Unde nihil prohibet eam in creato esse sicut in subiecto" ( $C G$, lib. 2 cap. 18). 
The phrase producere res in esse used by Aquinas breaks with the misinterpreted term creare. By reaching for the word producere (-duxi,-ductum), consisting of two words: the verb duco (-ere) (introduce, lead) and the prefix pro (to), he wants to draw our attention to the proper understanding of the act of creation, namely that creation is the introduction (ducere pro) of something into existence, something that has not yet been. Thus, in the act of creation, whole beings, with all their content-endowment, are called into existence. "Accidents and forms," explains Aquinas, "as they do not exist by themselves, so they are not created by themselves; because creation is the creation of being (productio entis); and as they are in something else, so are they created in other creatures." 32

As such, things are created as beings. An entity (a being) is characterized by: the law of identity - from the beginning an entity is what it is (e.g., a human, animal, plant, etc.), the law of non-contradiction-an entity is not a being and a non-being at the same time (e.g., an entity cannot both be human and non-human), the law of the excluded middle - an entity is not an intermediate (transitory) state between non-existence and existence (an evolutionary link), the law of the rationality of being - there is a reason set by the Creator for an entity's matter, form, and end-purpose, the law of finality-everything that exists in an entity is ordered towards this endpurpose; and the law of integrity (perfection) - an entity has everything that is necessary for its full development.

The most popular images and concepts that have been associated with creation in history are contained in the Platonic metaphor of a "craftsman's work," as taken from Timaeus. In this work, the building material of beings is not subject to creation. The concept of building material itself is diverse: whether as matter, as darkness, as disorder, as boundlessness, or as the patterns of things (ideas). The very moment of creation is connected with ordering, shaping, or forming something in this eternal material. Aquinas, in connection with this ingrained and widespread understanding of creation, put forward the clear thesis that the Creator "did not call things into existence from something that already existed, such as matter," $" 33$ and that everything that exists comes from Him: matter and form, substance and properties, and essence and existence. This makes sense because to create means to bring the whole of being itself into existence. ${ }^{34}$

\footnotetext{
${ }^{32}$ Ibid.

${ }^{33} C G$, lib. 2 cap. 16.

${ }^{34} C G$, lib. 2 cap. 18 n. 954: "Quia accidentia et formae, sicut per se non sunt, ita nec per se creantur, cum creatio sit productio entis: sed, sicut in alio sunt, ita aliis creatis creantur. Cf. STh I,
} 
4.1.2 Creation as "constitutio ipsa dependentia esse creati ad principium a quo statuitur"

The second important phrase that St. Thomas Aquinas introduces to show the specificity of creation is the term he used to describe creation as an act of introducing first relations and dependencies. ${ }^{35}$ In this formulation there is another element of the originality of his approach to the essence of the act of creation and the Creator himself as the Absolute. The Latin word "absolute" indicates such a Being that is not $(a b)$ bound (solutus) by any relationship with something else (solutus $a b=$ Absolutus); this Being is one in itself. The act of creation is precisely the moment when first relations, first references, are established (constituted) with the calling of beings into existence. These first references are real in created beings, and for this reason they are derivative and dependent beings (dependent on their Creator). For, as Aquinas explains, "accidents [relations are exactly that] and forms, just as they do not exist by themselves, they are not created by themselves (since it is the act of creation that brings beings into existence), but as they exist in something else, they are created together with that other thing." 36

Creation, being an act of the Creator's thought and will, and therefore a specific action, is not determined by anything: not by nature or any matter. With the act of the creation of a being, the first dependence of being is introduced and established: this dependence is the dependence of a created being's existence "on its source/beginning from which it originated." ${ }^{37}$ This relation is inscribed - in reality and in an actual manner (not potentially) in a specific, created being, which is the subject of this relation and, being itself, expresses the content of this relation. It is clear, adds Thomas, "that if creation is a certain relation, then it is something.... For since the created effect [of the action] depends in reality on the creator, this kind of relation must be something." 38

q. 45 a. 4 ad 2: "Ad secundum dicendum quod creatio non dicit constitutionem rei compositae ex principiis praeexistentibus: sed compositum sic dicitur creari, quod simul cum omnibus suis principiis in esse producitur."

${ }^{35} C G$, lib. 2 cap. 18 .

${ }^{36}$ Ibid.

${ }^{37}$ Ibid.: "ipsa dependentia esse creati ad principium a quo instituitur."

${ }^{38} C G$, lib. 2 cap. 18 n. 954: "Apparet autem, si creatio relatio quaedam est, quod res quaedam est.... Cum enim effectus creatus realiter dependeat a creante, oportet huiusmodi relationem esse rem quandam." Cf. De potentia, q. 3 a. 3 s. c. 1: "Si creatio non est aliqua res, ergo nec aliquid realiter creatur. Hoc autem apparet esse falsum. Ergo creatio aliquid est in rerum natura." Cf. STh I, q. 45 a. 3. 
This means that the act and the fact of creation begins and ends with the creation of a concrete being. The act of intellect and will is inscribed in things with their introduction into existence, in the form of an idea (project) and purpose which the Creator has given to things, and which things actualize in their existence, and which constitute a thing's truth and goodness. ${ }^{39}$ Moreover, it is the constitution of the intellect and the will by the Creator of the first existential relations (dependencies) that makes the created being exist as open (both cognitively and existentially) and refers those who cognize this being to their source, the Creator. ${ }^{40}$

An important achievement of Aquinas's theory of creatio ex nihilo, interpreted as the "constitution of first relations," is to show the ordering of every being to the thought and will of the Creator. In this way, human reason encounters in beings the intention and will of the Creator, which it can read, and which (being traces of the Creator's action) refer human reason to the Source and Reason of existence, rationality, and finality of those beings. The world of real beings stands before man as a book in which the Creator has written down the idea (design) and purpose of every being, as well as the truth about Himself. This creative relation, written in created things, as Aquinas explains, "does not refer to another relation (relatio non refertur per alias relationem) ... but refers to itself because it is essentially a relation (sed per seipsam refertur, quia essentialiter relatio est)." ${ }^{41}$ Therefore, the content of this relation can be read and recognized in, and together with, being, because that is where this relation is real. Thanks to this, in explaining the origins of the world, we avoid going into infinity (abire in infinitum), for our intellect is able to reach, by a cognitive reading of being, the ultimate source of existence, its rationality, and finality, namely the Creator.

\subsection{Selected Arguments in Favor of CREatio Ex Nihilo}

Aquinas attached great importance to philosophical (metaphysical) and rational argumentation. This is supposed to "overwhelm" the mind of the reader or listener and make the metaphysical theory of creatio ex nihilo be considered true and valid. He was aware of the revolution that this theory introduced in the field of philosophy - in fact, this theory changes the understanding of the creation of the world in general and of individual things, both

\footnotetext{
${ }^{39}$ Cf. $C G$, lib. 2 cap. 18.

${ }^{40}$ Cf. ibid.: "oportet huiusmodi relationem esse rem quamdam."

${ }^{41}$ Ibid.
} 
in relation to Aristotle and Plato and the broad patristic tradition, and-it should be added - to contemporary natural philosophers and naturalists.

\subsubsection{The Argument from Effect-Cause Analysis}

The first argument in favor of ex nihilo creation was based on an analysis of the effect-cause relation and on the principle of the impossibility of regresus in infinitum when indicating the causes of effects. Moreover, these effects are concrete beings. The Creator, Aquinas explains, by producing effects in the form of concrete beings, does not create any pre-existing matter upon which something else would work and produce effects. Otherwise, for matter understood in such a way, one should look for new causes, and for them-infinitely more or one should assume that created effects are not beings. Therefore, only the Creator who creates ex nihilo can be the absolute beginning and source of all beings. ${ }^{42}$

\subsubsection{The Argument from Distinguishing a Particular Cause from the Universal One}

In this argument, Thomas refers to the need to distinguish between a partial (particular) cause and the universal cause. He points out that the agent who needs some pre-existing matter through which he acts (e.g., only introduces a new form), is a partial (particular) cause. The Creator, on the other hand, is the universal cause and a common agent, that is to say, He is the cause of both individual things and of everything that makes up these things. ${ }^{43}$ As such, the Creator does not need pre-existing matter in His actions, but $\mathrm{He}$ brings things, that is, concrete beings, into existence with His own act of intellect and will. ${ }^{44}$

42 "Si igitur aliquid sit factum, oportet ex aliquo esse factum. Quod si etiam factum sit, oportet etiam et hoc ex alio fieri. Non potest autem hoc in infinitum procedere: quia sic nulla generatio compleretur, cum non sit possibile infinita transire. Oportet igitur devenire ad aliquod primum quod non sit factum" ( $C G$, lib. 2 cap. 34).

${ }^{43}$ The supporters of so-called evolutionary theism, who try to take the "Big Bang" as their first cause, face a double difficulty here. First, creation is an act of the intellect and will of the Creator, while an explosion is something accidental. Second, creation is the introduction to existence of beings as such, which from the beginning are something defined in terms of both content and existence, while the effect of an explosion is undefined.

${ }^{44}$ Cf. $C G$, lib. 2 cap. 16. 
4.2.3 Argument from Distinguishing between the Cause of Movement and the Cause of Existence

Aquinas indicates that the cause of existence is more common than the cause of movement. Not everything that exists, moves. However, everything that moves must first exist. Therefore, it is necessary that before (above) a cause which is only the cause of movement and change, is the cause which is above all the cause of existence. Any cause which - as a result of movement and change - can bring things into existence from pre-existing matter is a secondary cause to the one which can bring things into existence and do so without pre-existing matter. ${ }^{45}$ Even more, "what works only through movement and change," as the philosopher explains, "is not a proper universal cause, which is the cause of both a single thing and everything that exists. Through movement and change, there is no being in the absolute sense, but only this being from another being." 46

\subsubsection{The Argument from the Consistency Found between Action and Agent}

In the argument presented by this section title, Thomas refers to the appropriateness of action and the acting one. Everyone acts accordingly to the way he currently exists, that is, who and what he is. Giving form to already existing matter is appropriate for a being that has been actualized by the form it has, but such a being can only be the cause of the form embedded in matter. Hence material things, having forms that are embedded in their matter, are created by the action of material causes, which only actualize matter. For the creation of whole things, forms that exist by themselves are needed-forms that have the power to create substances. This can only be done by a Being whose proper mode of action is to call a whole thing into existence, and which exists by itself and does not need pre-existing matter in its action. Therefore, it is He who brings (pro-ducere) beings into existence ex nihilo. ${ }^{47}$

\footnotetext{
${ }^{45}$ Cf. ibid.

${ }^{46}$ Ibid.

${ }^{47}$ Cf. ibid.
} 


\subsubsection{The Argument from Analysis of the Transfer of Action}

Another argument for creating ex nihilo is built on an analysis of the cause that acts and communicates this action. However, action is a property of the agent and the one experiencing an action (the recipient). ${ }^{48}$ The cause of action, understood in this way, needs matter, as it relies on matter as its subject and perfects matter through action. However, this type of action is not a property of the creative cause, because the Creator does not act with actions that lie within Him as the subject of those actions, which are then received by some objects. This is because His action is His essence and substance. Hence, in order to have an effect He does not need a pre-existing matter, but He brings all things into being through acts of His intellect and will, called in this sense creatio ex nihilo. ${ }^{49}$

Moreover, an action that is related to pre-existing matter gets complicated when we notice that things have different matter. Spiritual beings do not have the same matter as bodily beings, and "heavenly" bodies are not the same as destructible bodies. The experience and acceptance of causation can therefore vary: in what is spiritual this is mental (the intellect takes in cognitive forms); for all "celestial" bodies it is a change of place and not a change of form of being. So, there is no "one matter that is in potency to the universal existence." can be the universal cause of everything that exists. This is precisely the Creative cause. The Creator brings beings into existence ex nihilo. ${ }^{51}$

\subsubsection{The Argument from the Priority of Act}

Another important argument, which Thomas Aquinas points out, is his reference to the priority of act over potency. Anything that is the cause and causes is in act. As he explains, the relation between act and potency is as follows: "In one and the same thing, which is sometimes in potency and sometimes in act, potency is before act as far as time is concerned. However, act is first in terms of the nature (of the undertaken action). Speaking in absolute terms, act must be earlier than potency," ${ }^{, 52}$ and it follows that only a being, which is in actu, actualizes potency. Assuming that matter is an

\footnotetext{
${ }^{48}$ The supporters of the "Big Bang" treat matter as a subject that is able to act.

${ }^{49}$ Cf. $C G$, lib. 2 cap. 16.

${ }^{50}$ Ibid.

${ }^{51}$ Cf. ibid.

${ }^{52}$ Ibid.
} 
eternal substrate, matter would have to be a being in potency and would not contain the reason of its existence. There must therefore be a being that is in act and is the reason for the existence of everything. Such is the Creator who brings everything into being ex nihilo. ${ }^{53}$

Therefore, we see that creation ex nihilo is the introduction of beingwith all its endowment and determination as to its essence and purposeinto existence and, most importantly, this is a momentary action (it takes place in a single moment), because there is nothing (and there cannot be anything) intermediate between being and non-being.

\section{THE PARADOXES OF EVOLUTIONARY THEISM IN THE CONTEXT OF CREATIO EX NIHILO METAPHYSICS}

Let us first note four important points. First, by evolutionism we mean a philosophical-biological theory that is applied to the whole reality as such and to every element of that reality (including the origins of species). ${ }^{54}$ This is what we call the theory of macroevolution and we distinguish it from the theory of microevolution, which concerns changes within species and is not a problem in terms of acceptance by metaphysics. Second, by theism we mean the type of metaphysical explanations in which we point to God as the first and necessary cause of the creation of the world and of individual beings. Third, the expression "evolutionary theism" is understood as a theory that seeks to combine the recognition of God as the Creator of the world and

\footnotetext{
${ }^{53}$ Cf. ibid.

${ }^{54}$ The climax of the dominance in the cultural and scientific sphere of the neo-Darwinian theory of evolution occurred in the 1950s. It was then (in 1959, to be precise) that the 100th anniversary of Darwin's work On the Origin of Species was celebrated. On this occasion, a worldwide celebration of this anniversary was held on the campus of the University of Chicago in November 24-28, 1959. Among the guests were Darwin's grandson, Charles Darwin, and T. H. Huxley's grandson, Julian Huxley. Issues related to the evolution of space, the evolution of life, the evolution of man, the evolution of societies, as well as the evolution of religion and ethics, were presented at this celebration as the results of scientific investigations which had the status of almost being certain (dogmatic). It was then that from the pulpit of the university chapel, Huxley (grandson) announced the end of all creationism. He said then: "All aspects of reality are subject to evolution, from atoms and stars to fish and flowers, from fish and flowers to human societies and values - in fact, all reality is one great evolutionary process.... In an evolutionary pattern of thinking, there is no longer any need or even any place for the supernatural" (Julian HuxLEY, "The Evolutionary Vision: The Convocation Address," in Issues in Evolution: The University of Chicago Centennial Discussions, vol. 3, Evolution After Darwin, ed. Tax Sol and Charles Callender [Chicago: University of Chicago Press, 1960], 249-61). Quoted in Michał ChABEREK, Kościót a ewolucja (Warsaw: Fronda, 2012), 44.
} 
the theory of evolution, according to which evolution is a "tool" used by the Creator. Fourth, one should distinguish the evolutionary theism postulated by some Christian natural philosophers and naturalists, ${ }^{55}$ thus referring to various philosophical traditions,${ }^{56}$ starting with the evolutionary theism promoted by some neo-Thomists who wish to reconcile evolutionary theism with the metaphysical creationism of St. Thomas Aquinas. This group of philosophers is directly referred to in this part of the article ${ }^{57}$ while certain arguments indicating an internal contradiction are also referred to (indirectly) as representative of "evolutionary theism" as formulated within the framework of other currents of philosophy and by representatives of different concepts of natural philosophy. Below are presented some selected aporias of evolutionary theism in the context of the metaphysics of creation.

\footnotetext{
${ }^{55}$ It is worth adding that, in the early years of the 21 st century, a group of scientific creationists emerged from the "Intelligent Design Movement," initiated by Phillip E. Johnson and his book Darwin on Trial (1991). The concept of Intelligent Design is a new kind of discussion with (neo-)Darwinism. It does not so much concern itself with correctness in interpreting the first chapter of Genesis, or with a biblical interpretation of the results of the natural sciences, as it does with considerations of the empirical evidence for Darwinism. This movement was formed in 1992 at a conference at the Southern Methodist University and its beginnings included such names as lawyer Phillip Johnson (Protestant), biochemist Michael Behe (Catholic), Stephen C. Meyer (philosopher of science), and William Dembski (analytical philosopher and mathematician, Protestant). In time, these people were joined by the agnostics David Berlinski and Anthony Flew. It has to be stressed that this movement is not another version of American creationism, but rather a movement that proposes a new methodological paradigm in science.

${ }^{56}$ Representatives of this type of evolutionary theism, in referring to process philosophy or other trends, should debate directly with representatives of the theory of evolution, and not with creationists, whether American or metaphysical (with the latter referring to the theory of Thomas Aquinas). The lion's share of Polish representatives of evolutionary theism do not discuss metaphysical creationism because it is either unknown to them or they identify it with American creationism.

${ }^{57}$ Cf. Nicanor P. G. Austriaco ET AL., Thomistic Evolution: A Catholic Approach to Understanding Evolution in the Light of Faith (Providence, RI: Cluny Media, 2016); Marie George, "What Would Thomas Aquinas Say about Intelligent Design?" New Blackfriars 94 (November 2013): 676-700; Michał CHABEREK, Aquinas and Evolution (Leicester: Chartwell Press, 2017) (the author points out issues contrary to evolutionary theism and Aquinas's metaphysics of creation); Piotr Lichacz, "Czy stworzenie wyklucza ewolucję?" in Teologia św. Tomasza z Akwinu dzisiaj, ed. Bogusław Kochaniewicz (Poznań: Uniwersytet Adama Mickiewicza, 2010), 71-94; Michał CHABEREK, “Tomasz z Akwinu a teistyczny ewolucjonizm," Zeszyty Naukowe 59, no. 1 (2016): 3-25.
} 


\subsection{Creation Is the Act of “One Moment," While Evolution TAKes Place over Time}

How does creation happen? Aquinas answers clearly: "Creation is done in an instant. Thus, at the same time something is being created and is created, just as something is being illuminated and is illuminated at the same time." 58 Even more, as a result of the act of creation, which takes place in a single moment (momentarily), as if out of time-because time starts with a beinga whole being is introduced into existence. What is a being is governed by the laws of identity, non-contradiction, the excluded middle, rationality, and finality. Moreover, the being introduced to existence in the act of creation is created with all its endowments: form and matter, substance and accidents, and essence and existence.

How, therefore, can we reconcile evolutionary theism, in which the formation of beings is a process taking place in time and nothing arises "momentarily" (as with the act of creation) which is beyond time and is the introduction of a whole being into existence "in one moment?" It does not seem possible to reconcile evolutionary theism with Aquinas's metaphysics of creation.

\subsection{There Is No Consequence in Creation, But Evolution Is Based ON CONSEQUENCES}

If one understands the act of creation properly, one should exclude consequence from it, emphasizes Aquinas. "The consequence," as he explains, "is a property of movement. Creation is not a movement or the end of the movement, which is change." ${ }^{, 59}$ Thence he goes on to explain that "in every movement in which there is a consequence, there is a middle between the two extremes; the middle is what a thing that moves on a continuous basis comes to before it comes to an end. Between being and non-being, which are like the two extremes of creation, there can be no middle. So, there is no consequence there." 60

58 "Creatio sit in instanti. Unde simul aliquid, dum creatur, creatum est: sicut simul illuminatur et illuminatum est" ( $C G$, lib. 2 cap. 19). Here, Aquinas was oblivious to the speed of light. Still, in this figure of speech he referred to what then seemed "instantaneous" (translator's note).

59 "Nam successio propria est motui. Creatio autem non est motus; nec terminus motus, sicut mutatio. Igitur nulla est in ipsa successio" (ibid.).

60 "In omni motu successivo est aliquid medium inter eius extrema: quia medium est ad quod continue motum primo venit quam ad ultimum. Inter esse autem et non esse, quae sunt quasi 
Meanwhile, in the process of evolution, which is a constant change (movement), there must be a succession of stages at which transitional forms of beings emerge. This, in turn, is a negation of the law of the excluded middle, which governs the existence of real things and which states that there is nothing intermediate between being and non-being. Similarly, it is a negation of the law of identity (a being is what it is) and non-contradiction (a being is not a non-being). Thus, evolutionary theism cannot be reconciled with Aquinas's metaphysics of creation.

\subsection{Becoming Is prior to the Formation of Being, While Creating Is Instantaneous}

"In every action in which there is a consequence," notes Thomas Aquinas, "becoming is prior to the fact of formation." 61 This is something we encounter in the process of evolution. However, becoming must take place in some subject, which is the matter existing before the created thing. Meanwhile, as he stresses, something like this "cannot happen in the process of creation, because the becoming that would have preceded the fact of creation would also require a subject." ${ }^{62}$ Such a subject could not be a being "whose creation we are discussing here because it does not exist." ${ }^{, 63}$ Moreover, he adds, "in the creative act ... nothing is necessary on the part of the matter, and the Acting One has everything that is necessary for His action, and can receive nothing more through movement, because He is immobile." 64

Meanwhile, in the process of evolution, the emerging being receives - as a result of change and movement-a new form, that is, something that it did not have before. Thus, it is impossible to reconcile evolutionary theism with Aquinas's metaphysics of creating ex nihilo.

extrema creationis, non potest esse aliquid medium. Igitur non est ibi aliqua successio" ( $C G$, lib. 2 cap. 19).

61 "In omni factione in qua est successio, fieri est ante factum esse" (CG, lib. 2 cap. 19).

62 "In omni factione in qua est successio, fieri est ante factum esse.... Hoc autem in creatione non potest accidere. Quia fieri quod praecederet factum esse creaturae, indigeret aliquo subiecto. Quod non posset esse ipsa creatura de cuius creatione loquimur, quia illa non est ante factum esse.... Relinqueretur igitur quod fieri haberet pro subiecto aliquam materiam facti praeexistentem. Quod est contra creationis rationem. Impossibile est igitur in creatione successionem esse" (ibid.).

${ }^{63}$ Ibid.

64 "In creatione autem nihil praeexigitur ex parte materiae: nec aliquid deest agenti ad agendum quod postea per motum ei adveniat" (ibid.). 


\subsection{Evolution as an Instrumental Cause and Creation as an Act}

Evolutionary theists postulate to treat evolution as an instrumental cause that God could use. Thomas makes this point clear: "It is not possible for any creature to create either as a primary cause or as a tool." ${ }^{25}$ Why? Because "in the order of generation, the effect corresponding to the proper action of a tool would be prior to the effect corresponding to the main cause.... Thus, something would have to be an effect caused by the proper action of the instrumental creative cause, which, in terms of generation, would precede the existence, which is an effect corresponding to the action of the first creative cause. This in turn is impossible-the more universal something is, the higher precedence it has in [the process of] generating."

Thomas rejected even more emphatically the view of those who saw secondary causes as the source of the creation of beings, as he states in the final sentence of the Second Book of Contra Gentiles (Chapter 21): "Through these considerations, the error of some philosophers who claimed that God created the first substance that existed separately, and that this created the second substance in some order until the last, is refuted." ${ }^{67}$ Furthermore, to create is to bring a being into existence. And this being is something that already has a specific essence and an existence proportional to it.

Thus, it is difficult to reconcile the postulate of evolutionary theism that God used evolution as an instrumental cause in calling the whole of being into existence, because this is contrary to the properly understood metaphysics of creation ex nihilo, as presented by St. Thomas Aquinas.

\subsection{The Source of the Diversity of Beings and Secondary Causes}

The question regarding the multiplicity of species, and thus the diversity of beings, is posed by Aquinas in Chapter 42 of the Second Book of Contra

\footnotetext{
65 "Impossibile est ergo quod aliqua creatura creet, neque sicut principale agens neque instrumentaliter" ( $C G$, lib. 2 cap. 21).

66 "Effectus autem respondens actioni propriae instrumenti est prior in via generationis quam effectus respondens principali agenti, ex quo provenit quod primo agenti finis ultimus respondet: prius enim est sectio ligni quam forma scamni, et digestio cibi quam generatio carnis. Oportebit igitur aliquid esse effectum per propriam operationem instrumentalis creantis quod sit prius in via generationis quam esse, quod est effectus respondens actioni primi creantis. Hoc autem est impossibile: nam quanto aliquid est communius, tanto est prius in via generationis" (ibid).

67 "Per haec autem destruitur quorundam philosophorum error qui dixerunt Deum creasse primam substantiam separatam, et ab ea fuisse creatam secundam, et sic quodam ordine usque ad ultimam" (ibid.).
} 
Gentiles. Already in the very title of the book he puts forward the thesis that "the first cause of the diversity of things is not the order of secondary causes." Here he recalls the assertions of "some" philosophers who claimed that "God, being one and undivided, produces only one effect, which is the first created substance, which, since it cannot match the undividedness of the first cause, is not pure [act], but, having somehow an admixture of potency, possesses a certain multiplicity, so that from it a multiplicity can already arise. And so, since the effects are never as little complex as the causes, when the effects multiply, the variety of things that the universe is made up of is created." ${ }^{, 69}$

This is one of the problems of evolutionary theism, whose absurdity, in light of Aquinas's metaphysics of creation ex nihilo, is in no way doubtable. If such an explanation were accepted, "the differences ... between things and the order of the universe would come from chance." ${ }^{70}$ Moreover, the best order is the order of the universe, which concerns the diversity of all things, and which is, in itself, good. Therefore, the proper cause of this order can only be the Creator. "So," Aquinas concludes, "the diversity of things that the order of the universe is based on do not come from secondary causes, but rather from the intention of the first cause." $" 71$

"What is more," he adds, "in things that come into being thanks to the intellect, the form that comes into being in created things comes from a similar form that is in the intellect, just like (for example) a materially existing house comes from a house that exists in the intellect. The form of diversity and order can only occur within an active intellect if there are also forms of different and ordered things in it. Thus, there are forms of different and ordered things in God's intellect, which does not contradict God's undividedness... So, if from the forms that are in the intellect come things that are outside the soul, then among the things that are caused by the intellect many and various things can come directly from the first cause." 72

We see, therefore, that attempts to explain the diversity of species by attributing the formation of these species to secondary causes (which necessarily must be accepted by evolutionary theists) are irreconcilable with Aquinas's metaphysics of creation.

\footnotetext{
68 "Quod causa prima distinctionis rerum non est secundorum agentium ordo" (CG, lib. 2 cap. 42).

${ }^{69}$ Ibid.

${ }^{70}$ Ibid.

71 "Oportet igitur ordinem universi sicut in causam propriam reducere in Deum, quem supra ostendimus esse summum bonum. Non igitur rerum distinctio, in qua ordo consistit universi, causatur ex causis secundis, sed magis ex intentione causae primae" (ibid.).

${ }^{72}$ Ibid.
} 


\subsection{First Matter and the Evolution that “Forms” Beings}

One of the main problems of the theory of evolution is the appearance of new forms (species) of things. Where do these forms come from? Can matter itself emerge from them? Thomas Aquinas answers: "Matter first could not exist by itself prior to all the other formed bodies, because it is only potency, and every real existence comes from some form.... Existence, on the other hand, pertains not just to a form or to matter, but to that which is composed [of them], because matter exists only in potency, and form is what makes something something-because it is realization. From this it follows that, in the proper sense of the word, what is composite, exists." ${ }^{, 73}$ Aquinas explains further: "The first introduction of forms into matter cannot come from a cause that only acts through movement, because every movement towards a form goes from a form, what is defined - towards a defined form, because matter cannot exist without any form-hence why the existence of some form in matter is assumed. Every cause acting only towards the realization of a material form must be the cause acting through movement. Since material forms are not intrinsically self-sufficient, but their existence consists in their existence in matter, they can only be called into existence either by the creation of the whole composite thing or by the passing of matter under the influence of such and such a form. It is therefore impossible for the first introduction of forms into matter to come from someone who only creates form, but must come from the one who is the creator of the whole composite thing., 74

Aquinas adds that "the first establishment of these forms, for the creation of which [i.e., their actualization, as they are stored in the potency of matter] the movement of the heavens is not sufficient, if there are no similar forms in the species beforehand, must come only from the creator." "75

So, how to reconcile the statement of metaphysics that "what is in act, acts" with a process? Evolution is not something that is in actu, nor is it a pure act. So, how could evolution be the cause of the actualization of forms that would have been stored in the potency of matter? This aporia, too, is unsolvable in the context of the metaphysics of creation.

\footnotetext{
${ }^{73} C G$, lib. 2 cap. 43.

${ }^{74}$ Ibid.

${ }^{75}$ Ibid.
} 


\section{CONCLUSION}

Selected aporias, which give rise to evolutionary theism, the representatives of which are looking for compatibility with Thomas Aquinas's metaphysics of creatio ex nihilo, entail several comments and proposals. First, properly understood metaphysical creationism (free from ideologization, deformation, and ignorance) falsifies the theory of evolutionary theism. Second, it opens a discussion about the beginnings of the world and man, which should take place primarily in the area of metaphysics, the competence of which is to search for the ultimate causes of the existence of all things. Third, it is necessary to follow the inquiries and results of natural-cosmological sciences, which can serve as inspiration for new questions and as the exemplification of metaphysical theses, with this allowing for the preserving of the autonomy of metaphysics and metaphysical explanations in terms of their object, method, and purpose. Fourth, the supporters of evolutionary theism should realize that the rejection of the theory of act and potency within the areas of the philosophy of nature, philosophy of biology, philosophy of physics and philosophy of cosmology - the very theory that constitutes the basic and universal methodological instrumentarium that makes it possible to explain the creation of beings, their change, modification, alternation and dynamism - entails the necessity of adopting another theory-the theory of evolutionary theism - as the new methodological instrumentarium. This has become a kind of "trap" for contemporary Christian philosophers of nature and requires a rethinking and reopening.

\section{BIBLIOGRAPHY}

Aquinas. Summa Contra Gentiles. Vol. 2, edited by Pietro Caramello, Pietro Marc, and Ceslas Pera. Taurini: Marietti, 1961.

AQuinas. Summa Contra Gentiles: prawda wiary chrześcijańskiej. Vol. 1. Translated by Zofia Włodek and Włodzimierz Zega. Poznań: W Drodze, 2003.

Aristotle. Metafizyka. Translated by Tadeusz A. Żeleźnik. Polish translation edited by Mieczysław Albert Krąpiec and Andrzej Maryniarczyk. Lublin: Polskie Towarzystwo Tomasza z Akwinu, 2017.

Austriaco, Nicanor Pier Giorgio, James Brent, Thomas Davenport, and John Baptist Ku. Thomistic Evolution: A Catholic Approach to Understanding Evolution in the Light of Faith. Providence, RI: Cluny Media, 2016.

Chaberek, Michał. Aquinas and Evolution. Leicester: Chartwell Press, 2017.

Chaberek, Michał. Kościół a ewolucja. Warsaw: Fronda, 2012. 
Chaberek, Michał. “Tomasz z Akwinu a teistyczny ewolucjonizm.” Zeszyty Naukowe KUL 59, no. 1 (2016): 3-25.

George, Marie. "What Would Thomas Aquinas Say about Intelligent Design?" New Blackfriars 94 (November 2013): 676-700.

Huxley, Julian. "The Evolutionary Vision: The Convocation Address." In Issues in Evolution: The University of Chicago Centennial Discussions, vol. 3, Evolution After Darwin, edited by Sol Tax and Charles Callender, 249-61. Chicago: University of Chicago Press, 1960.

Jodkowski, Kazimierz. Spór ewolucjonizmu z kreacjonizmem. Podstawowe pojęcia i poglądy. Warsaw: Megas, 2007.

KAmiŃSKI, Stanisław. "Explanation in Metaphysics. Wyjaśnianie w metafizyce." In Stanisław KamiŃski, On the Methology of Metaphysics. Z metodologii metafizyki, 176-202. LublinRome: Polskie Towarzystwo Tomasza z Akwinu, 2018.

KrąPIEC, Mieczysław A., and Stanisław KamiŃski. "The Specificity of Metaphysical Cognition. Specyficzność poznania metafizycznego.” In Stanisław Kamiśski, On the Metaphysical Cognition. O poznaniu metafizycznym, 9-94. Lublin-Rome: Polskie Towarzystwo Tomasza z Akwinu, 2020.

KLoskowski, Kazimierz. Filozofia ewolucji i filozofia stwarzania. Warsaw: Wydawnictwo ATK, 1999.

Lichacz, Piotr. "Czy stworzenie wyklucza ewolucję?” In Teologia św. Tomasza z Akwinu dzisiaj, edited by Bogusław Kochaniewicz, 71-94. Poznań: Uniwersytet Adama Mickiewicza, 2010.

MaryniarczyK, Andrzej. “'Parvus Error in Principio Magnus Est in Fine.' Thomas Aquinas's Reinterpretation of the Understanding of Being and Essence as the Basis for the Discovery of the First Cause as 'Ipsum Esse'." Roczniki Filozoficzne 67, no. 4 (2019): 27-51.

Maryniarczyk, Andrzej. Dlaczego stworzenie 'ex nihilo'. Teoria metafizycznego kreacjonizmu. Lublin: Polskie Towarzystwo Tomasza z Akwinu, 2018.

SzumERA, Grzegorz. Metafizyka stworzenia: Świętego Tomasza z Akwinu teoria creatio ex nihilo. Lublin: Towarzystwo Naukowe KUL, 2017.

ŻyCiŃsKi, Józef. Bóg i stworzenie. Zarys teorii ewolucji. Lublin: Gaudium, 2011.

ŻyciŃski, Józef. God and Evolution. Fundamental Questions of Christian Evolutionism. Translated by Kenneth W. Kemp and Zuzanna Maślanka. Washington, DC: Catholic University of America Press, 2006.

\section{METAPHYSICAL CREATIONISM AND THE PARADOXES OF EVOLUTIONARY THEISM: A CONTRIBUTION TO THE DISCUSSION WITHIN CONTEMPORARY THOMISM}

\section{Su m m ary}

In this article I argue that metaphysical creationism that we encounter in the philosophy of St Thomas Aquinas, as opposed to American creationism and theological and biblical creationism, is a theory that stems from a purely philosophical explanation of the beginnings of the world and man. It is not, therefore, a biblical idea transferred to philosophy. Like the theism of the Aristotelian metaphysics, the theism of Aquinas's metaphysics is not a religious (theological) theism, but a purely philosophical (metaphysical) theism, because it stems from a metaphysical explanation of reality. Metaphysical creationism is the ultimate explanation of the source of the existence of beings that are given to us in experience as both unnecessary in their own existence and changea- 
ble. American creationism, on the other hand, is a biological-cosmological interpretation of the biblical truth concerning the creation of the world within a certain time frame (the 7-day paradigm) and - at its starting point - refers to the data of Revelation, which it wants to confirm scientifically.

This article is divided into two parts. The first part presents the key elements of the metaphysical theory of ex nihilo creation and the understanding thereof. In the second part, the elements of evolutionary theism are recalled which, from the point of view of metaphysical creationism, are the source of various paradoxes and, at times, even absurdities, and thus demand reconsideration.

Keywords: metaphysics; metaphysics of creation; creation ex nihilo; evolutionary theism.

\author{
METAFIZYCZNY KREACJONIZM A PARADOKSY \\ TEIZMU EWOLUCYJNEGO: PRZYCZYNEK DO DYSKUSJI \\ W RAMACH WSPÓŁCZESNEGO TOMIZMU
}

Streszczenie

Autor artykułu dowodzi, że metafizyczny kreacjonizm, z którym spotykamy się w filozofii św. Tomasza z Akwinu, w odróżnieniu od kreacjonizmu amerykańskiego oraz teologiczno-biblijnego, jest teorią, która wyrasta z czysto filozoficznego wyjaśnianie początków świata i człowieka. Nie jest zatem ideą biblijną przeniesioną na teren filozofii. Podobnie jak teizm metafizyki Arystotelesa, a także teizm metafizyki św. Tomasza z Akwinu nie jest teizmem religijnym (teologicznym), lecz teizmem czysto filozoficznym (metafizycznym), gdyż wyrasta z metafizycznego wyjaśniania rzeczywistości. Kreacjonizm metafizyczny jest ostatecznym wyjaśnieniem źródła istnienia bytów, które dane są nam w doświadczeniu, jako niekonieczne w istnieniu i zmienne. Natomiast kreacjonizm amerykański, jest interpretacja biologiczno-kosmologiczną biblijnej prawdy o stworzeniu świata w określonym przedziale czasowym (paradygmat 7 dni) i w punkcie wyjścia odwołuje się do danych Objawienia, które chce naukowo potwierdzić

Artykuł został podzielony na dwie części. W części pierwszej zostały przedstawione węzłowe elementy metafizycznej teorii stworzenia ex nihilo i jej rozumienie. W drugiej zaś części artykułu zostały przywołane elementy teizmu ewolucyjnego, które z punktu metafizycznego kreacjonizmu są źródłem różnych paradoksów, a niekiedy i absurdów oraz domagają się ponownego przemyślenia.

Slowa kluczowe: metafizyka; metafizyka stworzenia; creatio ex nihilo; teizm ewolucyjny. 